\title{
Evaluation of Operating Performance of the Reactor Coolant System of RSG-GAS using ChemCad6.1.4
}

\author{
Sukmanto Dibyo¹, Ign.Djoko Irianto', Santosa Pujiarta² \\ ${ }^{1}$ PTKRN BATAN, Gedung 80 kawasan Puspiptek Serpong \\ 2PRSG BATAN, Gedung 30 kawasan Puspiptek Serpong
}

\section{Abstract}

Evaluation of the operation of reactor main coolant system RSG-GAS is very important. This is related with the operation of the reactor that has been going on more than 27 years although the current reactor coolant system is still operating safely. The main coolant system RSG-GAS including both the primary and secondary cooling system. Evaluation can be conducted by calculating the coolant system performance by using the ChemCad6.1.4 software. Furthermore, this calculation result is compared with the most recent measurement in the cooling system operation. By this way it can be known the performance degradation in the Reactor Coolant System operation. The operating parameter data of primary and

Corresponding Author:

Sukmanto Dibyo,

email: sukdibyo@batan.go.id

Received: 29 July 2016 Accepted: 21 August 2016 Published: 21 September 2016

\section{Publishing services} provided by Knowledge E

(c) Sukmanto Dibyo, et al. This article is distributed under the terms of the Creative Commons Attribution License, which permits unrestricted use and redistribution provided that the original author and source are credited.

Selection and Peer-review under the responsibility of the ICONETS Conference Committee.

\section{G OPEN ACCESS} secondary cooling system are temperature, pressure and flow rate of coolant. The reactor operation at the power of $15 \mathrm{MW}$ is used as a reference data. The calculation result shows that the temperature parameter between calculation by ChemCad and the measurement data qualitatively is no significant deviations. However in the secondary coolant system, the outlet pressure of both heat exchanger nozzles are 0.8 bar and 1.2 bar that indicate lower than the calculation results. It's may be caused by the flow disturbances through the tube-side of heat exchangers. In generally the existing operating parameters on the reactor cooling system in terms of safety aspects still under safely condition.

\section{Keywords: evaluation, cooling system RSG-GAS, ChemCad6.1.4}

\section{Introduction}

Evaluation of operating data on the reactor main cooling system RSG-GAS is very important because this is related with the operation of the reactor that has been going on since the year of $1987[1,2]$. Analysis of cooling system for the RSG-GAS reactor has been performed by modeling of steady-state using RELAP 5 several years ago [3]. To obtain the results of an evaluation of the RSG-GAS reactor operation, it can be performed using the ChemCad6.1.4 software. Although the current operating condition of reactor still meets the high safety criteria, but to ensure that the reactor remains can be operated reliably. Therefore, the evaluation of primary and secondary cooling system on steadystate is one thing that is very meaningful.In operation of Reactor Coolant System RSGGAS, currently indicates that the reactor is operated safely [4], where the integrity of the reactor core can be maintained against damage caused by high temperature of coolant. 
Therefore, to obtain a high confidence to the safety aspects of such reactor operation, it is necessary also to evaluate the operation conditions of Reactor Cooling System.

The evaluation is conducted by comparing the measured data with the calculation results of operating parameters such as the temperature, pressure and flow rate of cooling systems. Recently, the reactors usually operate at a power of $15 \mathrm{MW}$, therefore the reference data of 15 MW reactor power is used.

At first step, the evaluation of operating parameters in the cooling system is to create the flow diagram of cooling system and the input parameter using the ChemCad6.1.4 Software. The input data without degradation of performance components particularly in the heat exchanger can be applied. In this case, there is any possibility of decreasing the heat transfer coefficient [5]. On the other hand, the degradation of whole cooling system commonly that caused by the aging of component may be also evaluated. Furthermore, the calculation result can be compared to the measurement data of the cooling systems. In addition, the evaluation regarding to the Reactor Cooling System RSG-GAS have also been done by previous activities $[4,6]$.

The ChemCad6.1.4 is a program that capable to be used to design the operation, evaluation at the industry of process equipment manufacturing, analysis of unit operation, the process instalation including for the new designs (equipment sizing) of reactor cooling system [7]. The ChemCad software has been successfully applied in the design of cooling system for OPAL Research Reactor $20 \mathrm{MWt}$ Australia [8]. The program can quickly configure a graphical flowsheet, user friendly and component data completely if compared to other software such as cycle-tempo and HTRI's.

The purpose of this paper is to evaluate the operation parameter of main Reactor Cooling System RSG-GAS at the steady state operating condition. The evaluation is carried out by comparing the most recent measurement in the cooling system operation with the calculation results from the ChemCad6.1.4 SOFTWARE. Such operation parameter are primary cooling temperature, secondary cooling temperature, pressure and coolant flow rates.In the evaluation of this cooling system, the evaluation of operation parameter beyond of main Reactor Cooling System (such as emergency system, water purification system etc) are not considered.

\section{Reactor CoolANT System of RSG-GAS}

The main Reactor Coolant Systems consist of the primary cooling system, the secondary cooling system and the pool cooling system are shown in Figure 1, schematically. The primary and secondary cooling systems are to assure safe temperatures in the core at normal operation. During power operation of the reactor, the heat released in the core is removed by the water of the primary cooling circuit which flowing downwards through the core. The primary cooling system is cooled by two units of heat exchangers, through which heat is transferred to the secondary cooling circuit and then dissipated to the atmosphere through mechanical draft cooling towers. The main components of the cooling system consist of the primary cooling pumps, primary heat exchangers and cooling tower [9]. To monitor the operating parameter data of cooling system are provided by the measuring instrument such as flow rate, temperature, pressure and other indicators. The Flow Diagram as depicted in Figure 1, the temperature and pressure indicators are located in the position that related to the operating data of cooling systems, such as a temperature indicator is installed in the cooling flow line to the reactor, the main suction line before the primary cooling pumps, the 
primary cooling inlet and outlet temperatures of each heat exchanger, secondary coolant outlet temperature from cooling towers. Further pressure indicators are located in the suction and discharge nozzles of the primary cooling pumps and secondary cooling pumps. A standard orifice is provided in the suction branch of each pump and indicates continuously the flow of each pump with analogue recorder. Furthermore, the flow of coolant pressures and temperatures that measured in each section.

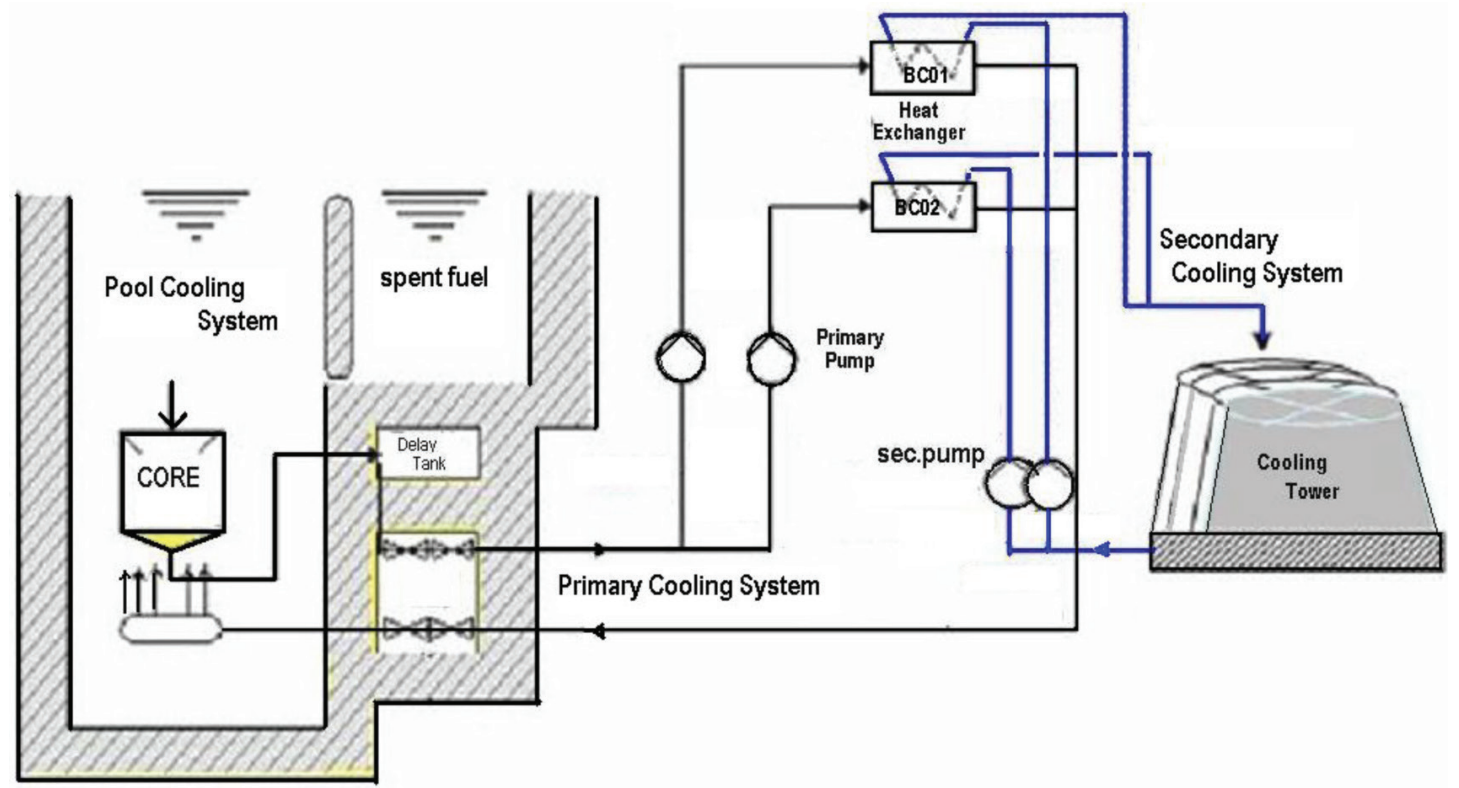

Figure 1: Flow Diagram of Main Reactor Coolant System [9].

\section{Chemcad6.4.1 Software}

The ChemCad software is a tool to analyze both steady-state and dynamic systems. The software uses Visual Basic Applications, and it can calculate the modeling continuous, batch, and semi-batch processes. The software is used for the design, operation, and maintenance of chemical processes in a wide variety of industries, including oil and gas production, refining, gas processing, biofuels and process equipment manufacturing [10]. Optimization calculations can also be made to the existing process, the rating on vessels, columns, heat exchangers, piping, valves and instrumentation. In the application of ChemCad, it can quickly configure a graphical flowsheet of simple or complex processes and then enter data in a Windows format to calculate the process, mass and energy balances. The software is user friendly and interactive because it directly inform less input or if an error has occurred. However, the user should have an understanding toward the principles of unit operation process.

Description of module feature contained in the ChemCad6.1.4 are as follows:

1. CC-Steady State.

The main ChemCad product, known as CC-Steady State, enables you to design new processes, rate existing processes, and optimize processes in steady state.

2. CC-Dynamics

The module known as CC-Dynamics makes it possible to design and rate existing processes using a dynamic simulation. This module is fully integrated with ChemCad to 
make switching between steady state and dynamics easy and intuitive. By using CCDynamics, its can easily simulate everything from simple to complex control systems.

3. CC-Batch

This module enables to design, rate, or optimize a batch column. CCBatch includes a scheduling interface to allow an "operation step" approach to simulation of batch columns.

4. CC-Therm

The CC-Thermis used to design a single heat exchanger, or vet a vendor'sheat exchanger design. It is also ideal to rate existing exchangers in new service, or to perform calculations on hypothetical situations. CC-Therm can simulate shell-andtube, air-cooled, plate-and-frame, and double-pipe exchangers. Full integration with Chemcad makes it possible to calculate exit conditions from exchanger geometry for high-fidelity simulations.

5. CC-safety net

The CC-Safety NET provides the capability to design or rate piping networks and safety relief devices and systems, in both steady-state and dynamic systems. The steady-state features of CC-Safety NET are included with CC steady-state. This product enables to make simultaneous flow and pressure balanced simulations even in reverse-flow situations for single or multi-phase flow.

\section{Evaluation Methodology}

The evaluation methods used in the analysis of Reactor Coolant System are systematically shown in Figure 2 as follows,

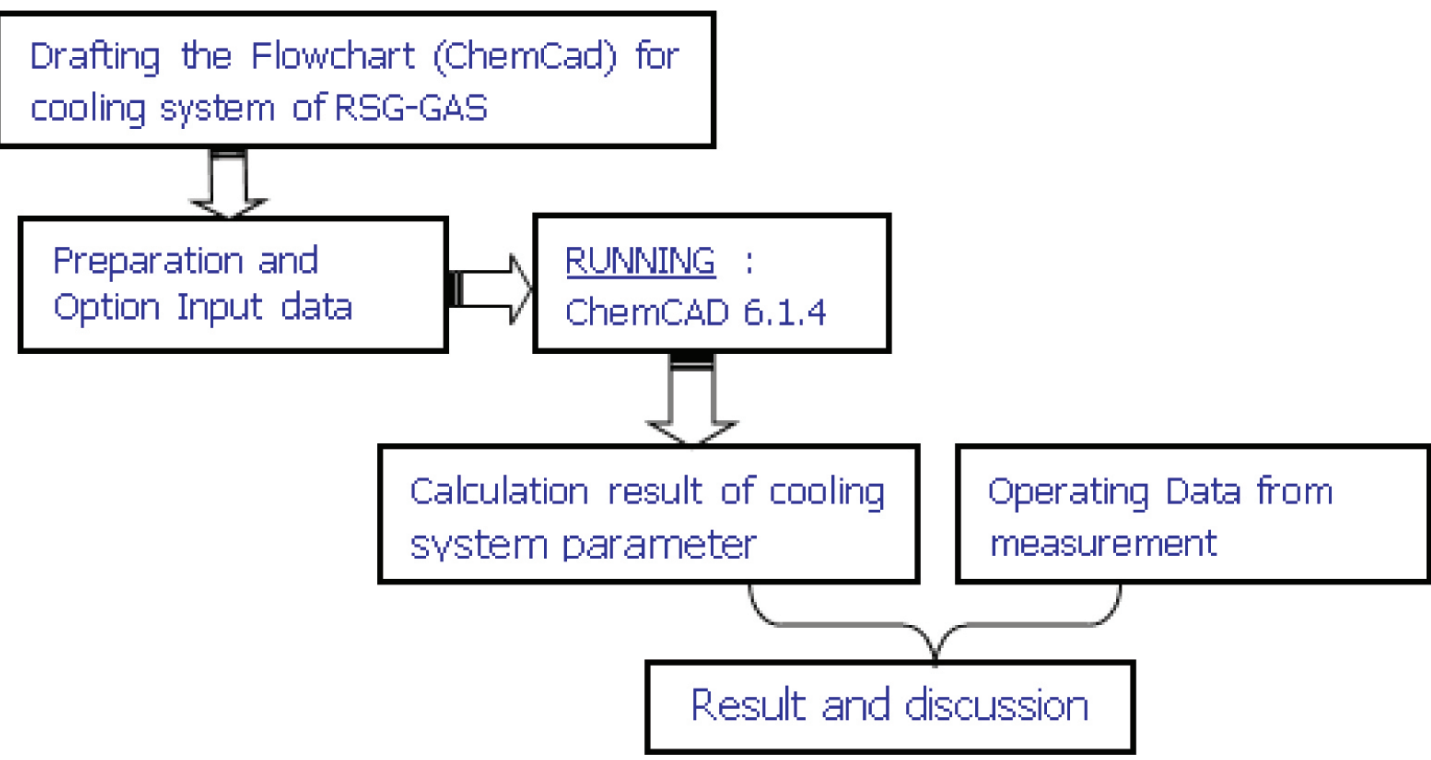

Figure 2: Schematic Flow Diagram for Evaluation.

Based on the drafting of flowchart and input data used for cooling system of RSG-GAS running the ChemCad is carried out. The running results and operating parameter of cooling system from measuring data of stream are evaluated by running the model [11]. 
Result and discussion focuses to the output of data analysis result and the data of operating measurement. Before running, the operating data parameters are evaluated, including temperature, pressure and flow rate. The input data of flowrate related to the coolant system are shown in Table 1 as follows:

TABLE 1. Input data of Flowrate.

\begin{tabular}{|c|l|c|}
\hline No & \multicolumn{1}{|c|}{ Parameter } & Nilai \\
\hline 1 & Volumetric flowrate of primary coolant line-1, $\mathrm{m}^{3} / \mathrm{h}$ & 1550 \\
\hline 2 & Volumetric flowrate of primary coolant line-2, $\mathrm{m}^{3} / \mathrm{h}$ & 1600 \\
\hline 3 & Volumetric flowrate of secondary coolant line-1, $\mathrm{m}^{3} / \mathrm{h}$ & 1950 \\
\hline 4 & Volumetric flowrate of secondary coolant line-2, $\mathrm{m}^{3} / \mathrm{h}$ & 1950 \\
\hline
\end{tabular}

The primary cooling system is calculated in adiabatic system, there is no heat is absorbed from the air or released into the air. Heat generated from the reactor is only released through the secondary cooling system by the cooling tower. The reactor thermal power of $15 \mathrm{MWt}$ is used as a input data.

\section{Results and Discussions}

Based on the calculating results using the ChemCad software, the mass balance and heat balance in each of flow stream can be obtained. Mass and heat balance of the cooling system are quantitative data on the flow of coolant inlet, outlet and accumulated released in the system. At steady-state, mass and heat balance of the system components i.e inlet and outlet flow are equal [12]. So that the balance calculation is useful to evaluate the existing coolant system by analyzing the operating parameters of coolant system when the degradation of operating condition has not happened yet. By comparing the data operating parameter taken from measurement result so can be described the degradation of cooling system operating condition. In this evaluation, calculation of coolant system focuses only on the main line of primary and secondary cooling system for the parameter of temperature, pressure and flow rate. As notation here that this analysis does not involve the pool cooling system, spent fuel, emergency coolant system and purification systems.

According to the fundamental priciples of the system analysis, the calculation for cooling system must be carried out together with the apparatus of the flow sheet [13]. Figure 3 depicts the flow diagram of coolant system RSG-GAS that prepared using the ChemCad6.1.4 software as an output result of calculations. In this diagram, there are two lines of primary and secondary cooling system correspond with the existing diagrams of Reactor Coolant System RSG-GAS. The Figure 3 is also provided the location of parameter indicator of temperature, pressure and mass flow rate parameters for each stream [14]. Then there are both two rectangular and circle marks that indicate the stream number and unit operation component number.

Input data used in the evaluation of this cooling system are flow rate and inlet temperature of coolant to the reactor. While in the secondary coolant system, the water temperature of the cooling tower is $34^{\circ} \mathrm{C}$ correspond with the measurement data as input calculations.

Simulation of the RSG-GAS coolant system at reactor power of $15 \mathrm{MWt}$ has been done in which includes volumetric flowrate, temperature and pressure of coolant flow respectively. As shown in Table 2 that the parameter data available from the measurement results can be compared with the results of the analysis from the ChemCad6.1.4 software in the steady state 
condition. Its shows that with the assumption of adiabatic system, the temperature parameter between calculation result by ChemCad and measurement data in general is no significant differences (stream no.1, no.9, no.10, no.11, no.22 and no.27). This small difference as shown in Figure 4 is caused by the measurement data were not ignoring the existence of heat loss (< 1\%) flowing out from the Reactor Coolant System to the air [15].

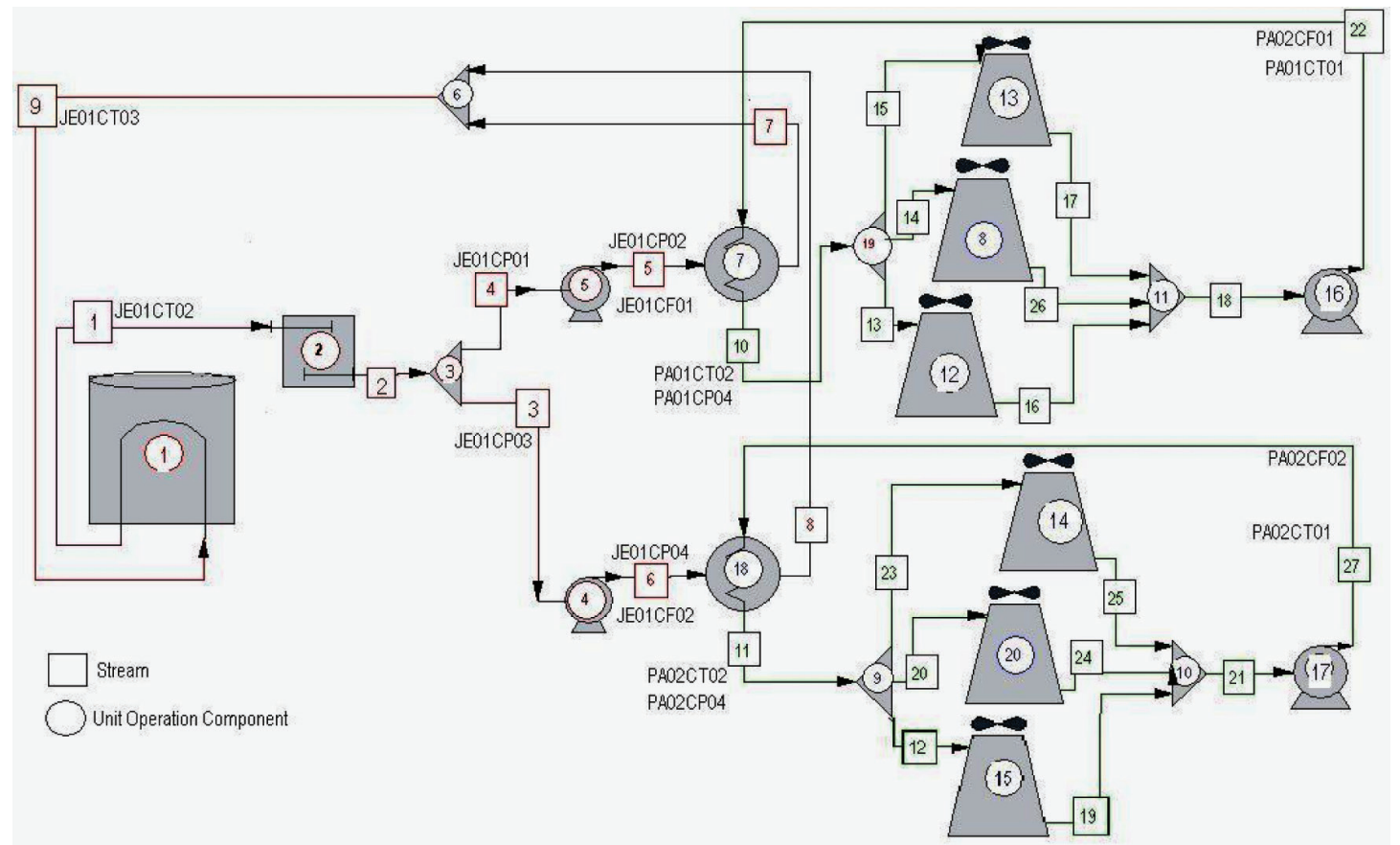

Figure 3: Flow diagram of coolant system RSG-GAS

There are differences flow pressure of primary as well as secondary system of line-1 and line-2 (as shown in Figure 4). In the suction side of the primary cooling pump (stream no.3 and no.4), the lower pressure than the calculation result occurred (Figure 5). This was may be caused by pressure drop along the flow line of suction side of primary cooling pumps. Meanwhile in the secondary cooling system, the outlet pressure of both heat exchanger nozzles are 0.8 bar and 1.2 bar (stream no.10 and no.11) shows lower than calculation results. Due to this calculation assuming the heat exchangers without fouling, therefore the high pressure drop excessively is also indicates the degradation performance of heat exchanger. Blockage by impurities cause a decrease in efficiency due to reduced heat transfer area and the increase in pressure drop [16]. As note information that the secondary cooling water from the cooling tower flows pass through the tube-side of heat exchangers. Its may be caused by the flow disturbances through the tube-side of heat exchanger.

The reactor power is indicated from the reference data which uses neutronic detector and refers to data calorimetric [17]. In this case the reactor power measurement does not involve the heat energy lost out from the coolant system to the environment. Differences may occur due to the reactor power calculated by ChemCad is based on the equation of thermal energy conservation, in which heat generated from the reactor are absorbed by the cooling system and there is no heat accumulated in the system. Besides, there are many factor possibilities that could cause these differences. Nevertheless in general the existing operating parameters of Reactor Coolant System in terms of safety aspects is still under safely condition. Coolant temperature to the reactor as a operational limit parameter of Reactor Protection System (RPS) is acceptable. 
TABLE 2. Operating Data of Cooling system RSG-GAS.

\begin{tabular}{|c|c|c|c|c|c|}
\hline No & Operating Parameter & Indicator & $\begin{array}{c}\text { Stream } \\
\text { no. }\end{array}$ & $\begin{array}{c}\text { Data meas- } \\
\text { ured }\end{array}$ & ChemCad \\
\hline 1 & Primary coolant temp. in-core, ${ }^{\circ} \mathrm{C}$ & JE01CTo3 & 9 & 36 & 36.0 \\
\hline 2 & Primary coolant temp. out-core ${ }^{\circ} \mathrm{C}$ & $\mathrm{JE01CTO2}$ & 1 & 41 & 41.5 \\
\hline 3 & Primary coolant pressure in-pump1, bar & JE01CPo1 & 4 & 0.20 & 0.30 \\
\hline 4 & Primary coolant pressure in-pumpz, bar & JE01CP03 & 3 & 0.15 & 0.30 \\
\hline 5 & Primary coolant pressure out pump1,bar & $\mathrm{JE01CP02}$ & 5 & 2.60 & 2.60 \\
\hline 6 & Primary coolant pressure out pumpz,bar & $\mathrm{JE} 01 \mathrm{CPO} 4$ & 6 & 2.65 & 2.60 \\
\hline 7 & Primary coolant flowrate-1, $\mathrm{m}^{3} / \mathrm{h}$ & JE01CFo1 & 5 & 1550 & 1550 \\
\hline 8 & Primary coolant flowrate- $2, \mathrm{~m}^{3} / \mathrm{h}$ & JE01CFo2 & 6 & 1600 & 1600 \\
\hline 9 & Secondary coolant temp in-BC $1^{\circ} \mathrm{C}$ & PA01CT01 & 22 & 34 & 34.0 \\
\hline 10 & Secondary coolant temp out-BC $1{ }^{\circ} \mathrm{C}$ & $\mathrm{PA01CT02}$ & 10 & 38 & 37.5 \\
\hline 11 & Secondary coolant temp in-BC $2{ }^{\circ} \mathrm{C}$ & $\mathrm{PA0} 2 \mathrm{CTO} 1$ & 27 & 34 & 34.0 \\
\hline 12 & Secondary coolant temp out- $\mathrm{BC} 2{ }^{\circ} \mathrm{C}$ & $\mathrm{PAO} 2 \mathrm{CTO} 2$ & 11 & 38 & 37.5 \\
\hline 13 & Secondary coolant flowrate-1, m³/h & PA01CF01 & 18 & 1950 & 1950 \\
\hline 14 & Secondary coolant flowrate-2, m³/h & PA02CF01 & 22 & 1950 & 1950 \\
\hline 15 & Secondary coolant press in-pump1 bar & - & 18 & - & 0.80 \\
\hline 16 & Secondary coolant press out-pump1 bar & $\mathrm{PAO}_{1} \mathrm{CPO}_{2}$ & 22 & 2.95 & 2.95 \\
\hline 17 & Secondary coolant press in-pumpz bar & - & 21 & - & 0.80 \\
\hline 18 & Secondary coolant press out-pumpz bar & $\mathrm{PAO} 2 \mathrm{CPO} 2$ & 27 & 2.95 & 2.95 \\
\hline 19 & Secondary coolant press out-BC1 bar & PA01CP04 & 10 & 0.80 & 1.30 \\
\hline 20 & Secondary coolant press out-BC2 bar & $\mathrm{PAO}_{2} \mathrm{CPO} 4$ & 11 & 1.20 & 1.80 \\
\hline 21 & Reactor power, MWt & & & 15 & 16 \\
\hline
\end{tabular}

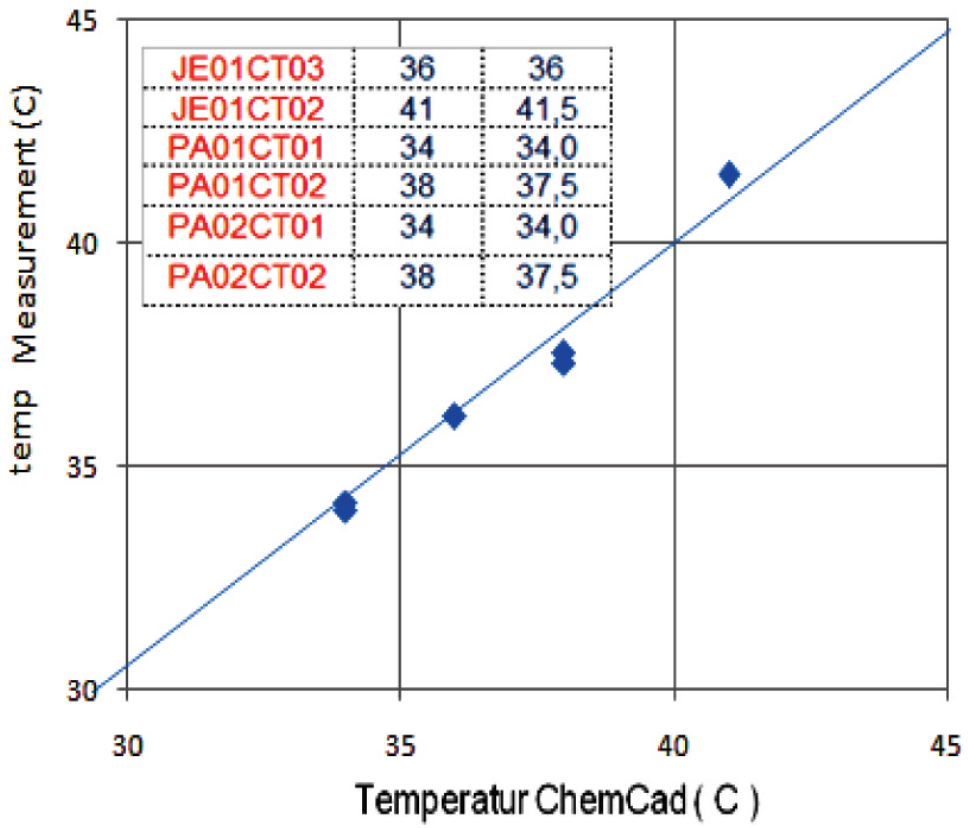

Figure 4: Curve of Temperature differences. 


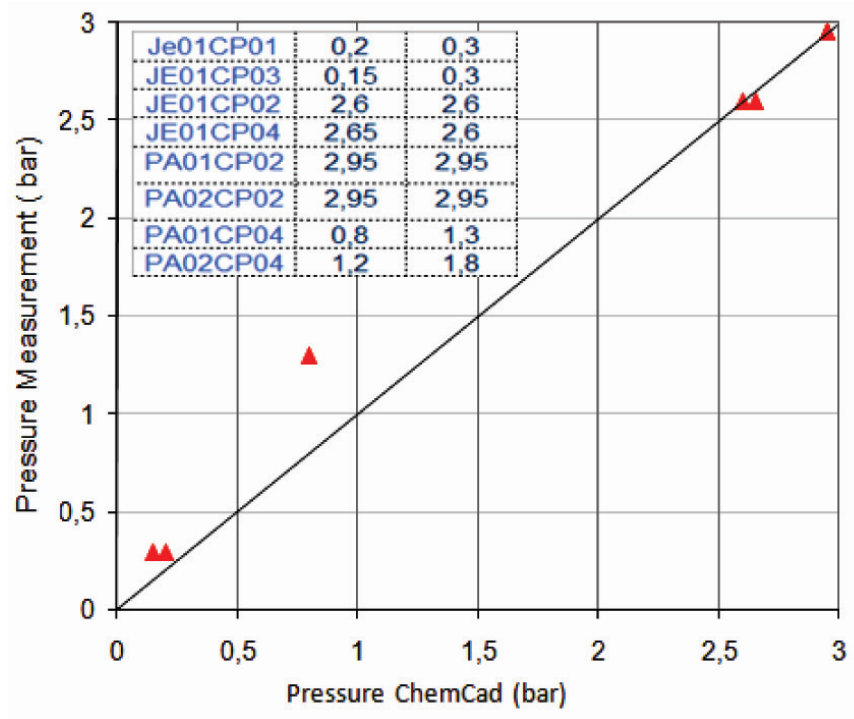

Figure 5: Curve of Pressure differences.

\section{Conclusion}

Based on the steady state calculation results of the reactor RSG-GAS at the power of $15 \mathrm{MW}$ shows that the coolant temperature parameter between calculation by ChemCad and the measurement data in general is no significant differences. However in the secondary cooling system, the outlet pressure of both heat exchanger nozzles indicates lower than the calculation results. It might be caused by the flow disturbances through the tube-side of heat exchangers. In general the existing operating parameters on the Reactor Coolant System in terms of safety aspects is still under safely condition.

\section{Acknowledgment}

The authors thanks to the Mr.M.Yahya, Head of System Mechanic Reactor Operation at Center for Multipurpose Reactor of BATAN for preparing the measurement data.

\section{References}

[1] Thantawi N,"Analysis For RSG-GAS Operation Characterictic of Reactor Cooling System", Prosiding Seminar Hasil Penelitian PRSG, p.303, 1998.

[2] Suroso,"Comprehensive Evaluation of Secondary Cooling System of RSG-GAS", prosiding Seminar Hasil Penelitian P2TRR, p.109, 2005.

[3] Dibyo S,"Validation of RSG-GAS Cooling System Model at Steady-State for the RELAP5. Mod3', Jurnal Teknologi Reaktor Nuklir; v.7(2); ISSN 1411-240X; Jun 2005.

[4] Iman K,"Evaluation on the Performance of Safety Systems of the RSG-GAS Reactor during 25 Years Operation", Bulletin of Nuclear Reactor Operation, p.1-10, Vol.11, No.1 2014.

[5] Durgesh B. et.al,"Shell and Tube Heat Exchanger Performance Analysis", International Journal of Science and Research (IJSR), Vol.3 Issue 9, Sept 2014,

[6] Purwadi MD,"Approach to the Aging Management of RSG-GAS", Prosiding Seminar Hasil Penelitian PRSG, p.161, 2005. 
[7] Herry Hartis,"Unsteady-State Simulation Using CHEMCAD", Process Engineering Associates, LLC June 2008.

[8] Invap, Reactor Cooling System and Connected Systems, RRRP-7225-SAR Chapter 6, ANSTO, Nov-2004.

[9] PRSG, LAK RSG-GAS, Chapter. 6, Rev. 10, 2011.

[10] Solanki K et.al,"Process Optimization Using ChemCad", Special Issue Azeotrope Vol:I, Issue:II Pub:2014, Page: 47-51, International Journal of Futuristic Trends in Eng. and Tech.

[11] Bhattarai M et.al,"Design of Shell-Tube Heat Exchanger (1-shell series \& 1-shell parallel)", INROADS-An International Journal of Jaipur National University, Vol3, Issue:151, 2014.

[12] Akram W.et.al,"Thermo-Hydraulic Behavior of Water Cooling Channel Subjected to Constant Heat Flux during Pressure Reduction Transient in its Cooling System", International Journal of Computer Applications (0975-8887) Vol 80, No 1, October 2013.

[13] Gartman T.N et.al," Experience in the application of the CHEMCAD program to the modeling of reactor processes", Theoritical Fundations of Chem.Engineering, Vol.43, No.6, 2009.

[14] Sudiyono,"Cooling System of The RSG-GAS, A Study of Disabilities", prosiding Seminar Teknologi Pendayagunaan Reaklor Riset G. A. Siwabessy; 130-137, 1995.

[15] Dibyo S," Assessment Of Heat Loss For RSG-GAS Primary Cooling System" Prosiding Seminar Hasil Penelitian PRSG1998.

[16] Dibyo S,"Analysis of Tube Plugging of the RSG-GAS Reactor Heat Exchangers", Jurnal Tekn. Reaktor Nuklir Vol. 9 No. 3 Oktober 2007.

[17] Slamet W, "Influence Of Fork-Absorber Test On Core Reactivity And Power Calibration RSG-GAS", Prosiding Seminar Penelitian Dan Pengelolaan Perangkat Nuklir, PTAPB, p.323, Yogyakarta, 27 Juli 2011. 